\title{
Uji Aktivitas Antioksidan Ekstrak Batang Tanaman Ungu (Graptophylum pictum (L.) Griff) Kabupaten Takalar Menggunakan Pereaksi DPPH Secara Spektrofotometri Visibel
}

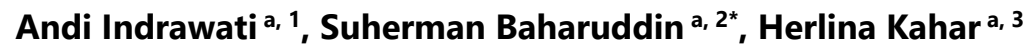 \\ ${ }^{a}$ Farmasi Universitas Indonesia Timut, Makassar, Sulawesi Selatan, Indonesia \\ 2 ince.suherman8I@gmail.com
}

*korespondensi penulis

INFO ARTIKEL

Diterima :

I4-OI-2022

Direvisi :

26-0I-2022

Disetujui :

30-0I-2022

\section{Kata kunci:}

Antioksidan;

Graptophylum pictum (L.)

Griff;

DPPH;

Spektrofotometri Visibel;

IC50.

\section{ABSTRAK}

Antioksidan adalah suatu sistem pertahanan dalam tubuh yang berguna untuk menangkal kerusakan sel tubuh yang disebabkan oleh radikal bebas. Berbagai kajian mengenai tanaman Graptophyllum pictum (L.) Griff dalam hal antioksidan, maka dalam penelitian ini akan dikembangkan pengujiannya sebagai antioksidan pada bagian batang dari tanaman Graptophyllum pictum (L.) Griff ini. Penelitian ini bertujuan untuk mengetahui dan menentukan ada tidaknya aktivitas antioksidan pada ekstrak batang tanaman daun Ungu (Graptophylum pictum (L.) Griff) Kabupaten Takalar dengan menggunakan pereaksi DPPH secara Spektrofotometri Visibel. Ekstrak batang tanaman daun Ungu dibuat dengan seri konsentrasi 50, 75, I00, I25 dan I50 ppm sedangkan vitamin $C$ sebagai pembanding dibuat dengan konsentrasi $2,4,6,8$, dan 10 ppm. Tiap seri konsentrasi ditambahkan DPPH 40 ppm dan diinkubasi selama 30 menit, lalu diukur absorbansinya menggunakan Spektrofotometri Visibel pada panjang gelombang $516.30 \mathrm{~nm}$. Nilai IC50 yang diperoleh dari ekstrak

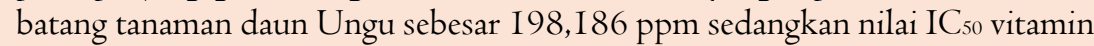
C sebesar 2,8I9 ppm. Hasil penelitian menunjukkan bahwa ekstrak batang tanaman ungu (Graptophyllum pictum (L.) Griff) Kabupaten Takalar memiliki aktivitas antioksidan lemah yang berada pada kisaran IC50 antara I5I200 ppm.

\section{Key word:}

Antioxidants;

Graptophylum pictum (L.)

Griff;

$\mathrm{DPPH}$;

Visible Spectrophotometry; IC50.

\section{ABSTRACT}

Antioxidants are a defense system in the body that is useful to ward off damage to body cells caused by free radicals. Various studies regarding the Graptophyllum pictum (L.) Griff plant in terms of antioxidants, so in this study will be developed as an antioxidant test on the stem of this Graptophyllum pictum (L.) Griff plant. This study aims to determine and determine the presence or absence of antioxidant activity in the stem extract of the purple leaf plant (Graptophylum pictum (L.) Griff) Takalar Regency using DPPH reagent by Visible Spectrophotometry. Purple leaf plant stem extracts were made with concentrations of $50,75,100,125$ and I50 ppm while vitamin $\mathrm{C}$ as a comparison was made with concentrations of $2,4,6,8$, and 10 ppm. Each concentration series was added with $40 \mathrm{ppm} \mathrm{DPPH}$ and incubated for 30 minutes, then the absorbance was measured using Visible Spectrophotometry at a wavelength of $516.30 \mathrm{~nm}$. The IC50 value obtained from the stem extract of the Purple leaf plant was I98.I86 ppm while the IC50 value for vitamin $\mathrm{C}$ was $2.819 \mathrm{ppm}$. The results showed that the stem extract of the purple plant (Graptophyllum pictum (L.) Griff) Takalar Regency had weak antioxidant activity in the IC50 range of I5I-200 ppm.

This is an open access article under the CC-BY-SA license. 


\section{Pendahuluan}

Saat ini dunia kesehatan dan pengobatan sedang banyak membahas tentang radikal bebas dan antioksidan. Hal ini terjadi karena sebagian besar penyakit diawali oleh reaksi oksidasi yang berlebihan didalam tubuh. Reaksi ini menghasilkan radikal bebas yang sangat aktif, yang dapat merusak struktur dan fungsi sel. Pembentukan radikal bebas dapat terjadi melalui proses metabolisme sel yang normal, inflamasi, malnutrisi, dan sebagai akibat dari respon terhadap reaksi dan pengaruh dari luar tubuh, seperti pencemaran lingkungan, ultraviolet, serta asap rokok (Sari, 2016).

Adanya radikal bebas dalam jumlah banyak merupakan masalah bagi kesehatan manusia karena atom atau partikelnya memiliki setidaknya satu atau lebih elektron yang tidak berpasangan (Nurwijayanto, et. al., 2020). Sifat antioksidan bahan kimia tanaman dapat membantu pencegahan suatu penyakit yang disebabkan oleh radikal bebas dan secara efektif memberikan efek tertentu bagi kesehatan. Cara terbaik untuk menetralisir atau melawan zat beracun, serta mengurangi terjadinya kerusakan suatu sel dalam tubuh yang disebabkan oleh proses oksidasi radikal bebas, adalah dengan menggunakan antioksidan (Lobo, et. al., 2010). Beberapa penelitian epidemiologis menunjukkan bahwa peningkatan penggunaan antioksidan alami yang ditemukan dalam buah-buahan, sayuran, tanaman beserta produknya memiliki manfaat yang sangat besar bagi kesehatan, hal ini disebabkan adanya beberapa sumber vitamin (A, C, E, dan folat), serat, dan kandungan zat lainnya, misalnya polifenol yang memiliki kemampuan menangkap radikal bebas (Herman, 2013). Suatu antioksidan alami didapat dari bagian suatu tumbuhan seperti kayu, kulit kayu, akar, daun, buah, bunga, biji dan serbuk sari, misalnya vitamin $A, B$ dan vitamin $E$ serta senyawa fenolik (flavonoid). Mikronutrien yang terkandung dalam tanaman ini memiliki kemampuan untuk menangkap suatu radikal bebas sehingga dapat digunakan sebagai pengganti dari antioksidan sintetis (Gill, et. al., 2002 ; Parwata, 2016).

Tanaman obat merupakan salah satu pemanfaatan keanekaragaman hayati yang ada di sekitar kita, baik tanaman yang dikembangkan maupun tanaman liar. Sejak dahulu kala, tanaman telah digunakan sebagai pengobatan konvensional. Perlu diingat bahwa biaya pengobatan tidak dapat dijangkau oleh semua orang, sehingga tanaman obat menjadi alternatif untuk digunakan oleh masyarakat (Bangun, 2012 ; Dewantari, et. al., 2018). Sebagaimana dikemukakan oleh Siswanto (I997), tumbuhan obat merupakan tumbuhan atau bagian tumbuhan yang dapat dimanfaatkan sebagai unsur pengobatan tradisional dan juga sebagai bahan baku utama obat, Tumbuhan atau bagian tumbuhan yang juga dapat dimanfaatkan sebagai obat melalui hasil ekstraksi (Qulbi, 2017).

Tanaman daun ungu adalah salah satu tanaman obat yang berasal dari Papua, namun saat ini juga banyak ditemukan di berbagai daerah seperti Jawa, Maluku, dan Ternate (Manoi, 2010). Tanaman berdaun ungu ini berasal dari Graptophyllum pictum (L.) Griff, famili Acanthacea yang memiliki kandungan berupa tanin, glikosida, dan alkaloid sitosterol yang digunakan untuk penyembuahn wasir, pencahar lemah, diuretik ringan. Dalam pengobatan tradisional, daun ungu digunakan untuk pengobatan terhadap luka, pembengkakan, bisul, luka terbuka, penyakit kulit, sementara itu dengan berbagai penelitian daun ungu ampuh dalam menghambat pembengkakan dan mengurangi permiabilitas pembuluh darah (Sumarny, et. al., 2013 ; Andiyani, et. al., 2015). Seperti yang dikemukakan oleh Kemenkes RI (20I2), senyawa aktif yang terkandung dalam daun ungu adalah flavonoid (4,5,7-trihidroksi flavonol, 4,4-dihidroksi flavon, 3,4,7-trihidroksi flavon dan luteolin-7-glukosida).

Tanaman daun ungu ini memiliki kemampuan yang disebabkan oleh adanya zat metabolit sekunder yang dikandungnya. Keberadaan zat metabolit sekunder tersebut pada tanaman sangat dipengaruhi oleh komponen intrinsik maupun ekstrinsik. Daun ungu mengandung zat metabolit sekunder seperti flavonoid, sitosterol, glikosida, saponin dan alkaloid yang tidak beracun (Rustini dan Ariati, 2017 ; Salim dan Suryani, 2020). Disisi lain daun tanaman ungu mengandung flavonoid, di mana flavonoid adalah sumber senyawa antioksidan alami dari golongan polifenol (Parwata, 2016).

Informasi dan berbagai penelitian tentang tumbuhan Graptophyllum pictum (L.) Griff ini telah dilakukan di berbagai bidang seperti pengujian dalam hal aktivitas antibakteri (Fauzi, 2016), dalam hal penyembuh luka (Andiyani, et. al., 2015), berfungsi dalam hal antioksidan (Haeria, 2013 ; Salim dan Suryani, 2020), sebagai antiinflamasi (Sya'haya, dan Iyos, 20I6), digunakan sebagai antidiare (Sumarny, et. al., 2013), sebagai bahan pengundukasi (Purwaningsih, 2019), antidiabetes (Theresia, 2012), dan digunakan sebagai aktivitas antijamur (Wahyuningtyas, 2008).

Berdasarkan berbagai uraian diatas dan berbagai kajian penelitian mengenai tanaman Graptophyllum pictum (L.) Griff, maka peneliti mencoba mengembangkan pengujian sebagai antioksidan pada bagian batang dari tanaman daun ungu, dimana tanaman ini diperoleh dari kabupaten Takalar Sulawesi Selatan dengan tujuan untuk mengetahui 
dan menentukan ada tidaknya aktivitas antioksidan pada ekstrak batang tanaman daun ungu (Graptophylum pictum (L.) Griff) kabupaten Takalar dengan menggunakan pereaksi DPPH secara Spektrofotometri Visibel.

\section{Metode}

\section{Alat dan Bahan}

Alat yang digunakan yaitu batang pengaduk, cawan porselin, corong kaca (Pyrex), erlenmeyer (Pyrex), gelas piala (Pyrex), gelas ukur (Pirex), labu tentukur (Pirex), mikropipet (Dragon Med), Seperangkat alat refluks (Pyrex), seperangkat alat rotary evaporator $\left(I k a^{\mathbb{B}}\right)$, spektrofotometer UV-Vis (UV-Mate), timbangan analitik (AND GR-300), timbangan analog (PGB). Bahan yang digunakan aquabides (WaterOne), DPPH (I,I-Diphenyl-2Picrylhydrazil) (TCI), Batang tanaman ungu (Graptophylum pictum), Etanol absolute (Merck), Vitamin C (asam askorbat) (Merck).

\section{Jalannya Penelitian \\ Pengambilan dan Pengumpulan sampel}

Sampel batang tanaman ungu (Graptophylum pictum (L.) Griff) diambil di Desa Aeng Batu-Batu, Kecamatan Galesong Utara, Kabupaten Takalar Provinsi Sulawesi Selatan.

\section{Proses Pengolahan Sampel \\ Penyiapan sampel}

Proses penyiapan sampel merujuk pada penelitian Haeria (2013), dimana batang tanaman ungu (Graptophyllum pictum (L.) Griff) yang telah diambil, dicuci hingga bersih dengan menggunakan air mengalir selanjutnya dipotong-potong kecil hingga dikeringkan dalam ruangan tanpa sinar matahari langsung. Setelah itu dilanjutkan pengeringan menggunakan oven dengan suhu $70^{\circ} \mathrm{C}$. Ekstraksi sampel

Ekstraksi sampel mengacu pada proses penelitian Susanty dan Bachmid F. (2016), dimana batang tanaman ungu yang telah diproses ditimbang sebanyak 25 gram lalu dimasukkan ke dalam labu alas bulat, selanjutnya ditambahkan pelarut etanol 75 $\%$. Dilakukan perangkaian alat refluks, sampel diekstraksi dengan suhu $50^{\circ} \mathrm{C}$ selama \pm 2 jam. Larutan yang sudah didapat dari hasil ekstraksi disaring dengan kain kasa steril serta kertas saring yang telah disterilisasi, lalu dimasukkan ke dalam wadah Erlenmeyer. Diulangi perlakuan dengan menggunakan sampel yang baru.

Evaporasi sampel

Larutan ekstrak yang didapatkan dari hasil ekstraksi dimasukkan ke dalam labu alas bulat dan dipasangkan kedalam alat rotary vacuum evaporator. Ditambahkan dengan air suling pada wadah air hingga batas yang telah ditentukan. Disaat yang sama dinyalakan pompa vakum serta mengatur alat rotary vacuum evaporator pada suhu $50^{\circ} \mathrm{C}$, tekanan 20 Psi dengan putaran $120 \mathrm{rpm}$. Proses evaporasi sampel dihentikan pada saat mulai terlihat batas garis tebal pada dasar labu dan larutan sudah dalam keadaan kental berwarna kecoklatan. Larutan ekstrak dioven hingga kering dengan suhu $50^{\circ} \mathrm{C}$ sehingga dapat diperoleh ekstrak pekat batang tanaman ungu. Proses selanjutnya dengan menimbang ekstrak pekat yang didapatkan (Susanty dan Bachmid, 2016).

\section{Penentuan Karakterisasi}

Penentuan hasil karakterisasi ekstrak batang tanaman ungu (Graptophyllum pictum (L.) Griff) meliputi rendemen, bentuk, warna, bau dan rasa.

\section{Pembuatan Larutan DPPH $40 \mu \mathrm{g} / \mathrm{mL}$}

Pembuatan larutan DPPH $40 \mathrm{ppm}$ dibuat dengan menimbang sebanyak $40 \mathrm{mg}$ DPPH dan dilarutkan dalam etanol $96 \%$ sampai batas $1000 \mathrm{~mL}$ (Sinala dan Dewi, 2019).

\section{Pengujian Aktivitas Antioksidan \\ Pembuatan dan pengukuran kurva baku (blanko)}

Memipet sebanyak $4 \mathrm{~mL}$ larutan DPPH $40 \mathrm{ppm}$ lalu dimasukkan kedalam tabung reaksi dan ditambahkan I mL etanol 96\% kemudian dikocok hingga homogen, diinkubasi kisran \pm 30 menit, selanjutnya diukur nilai absorbansinya pada panjang gelombang rentang $400 \mathrm{~nm}-800 \mathrm{~nm}$. Hasil yang didapatkan akan diperoleh panjang gelombang maksimum dan nilai absorbansi larutan standar DPPH 40 ppm (Sinala dan Dewi, 2019 ; Nurisyah, et. al, 2020].

Pembuatan dan pengukuran larutan pembanding vitamin $C$

Pembuatan larutan pembanding vitamin C baku I000 ppm dengan cara menimbang sebanyak 100 mg dan dilarutkan dengan etanol $96 \%$ hingga 100 $\mathrm{mL}$ Dibuat pengenceran larutan vitamin $\mathrm{C}$ dari larutan stock yaitu 2, 4, 6, 8, dan I0 ppm. Tiap-tiap larutan dipipet sebanyak I mL dimasukkan kedalam tabung reaksi yang telah ditutupi dengan aluminium foil dan ditambahkan $4 \mathrm{~mL}$ larutan DPPH $40 \mathrm{ppm}$. Larutan diinkubasi selama \pm 30 menit, selanjutnya diukur absorbansinya pada panjang gelombang maksimum menggunakan spektrofotometri UV-Vis (Salim, 2018 ; Sinala dan Dewi, 2019).

Pembuatan dan pengukuran aktivitas antioksidan ekstrak batang tanaman ungu (Graptophyllum pictum (L.) Griff) 
Pembuatan dan pengukuran aktivitas antioksidan mengacu pada penelitian Sinala dan Dewi, (2019) dengan cara dibuat larutan stock 500 ppm dengan melarutkan $25 \mathrm{mg}$ sampel ekstrak batang tanaman ungu kedalam labu ukur $50 \mathrm{ml}$ dengan etanol 96\%. Selanjutnya dibuat deret konsentrasi sampel 50, 75, I00, I25 dan $150 \mathrm{ppm}$. Tiap-tiap larutan dipipet sebanyak I $\mathrm{mL}$ dimasukkan kedalam tabung reaksi yang telah ditutupi dengan aluminium foil dan ditambahkan $4 \mathrm{~mL}$ larutan DPPH $40 \mathrm{ppm}$. Larutan diinkubasi selama 30 menit, kemudian diukur absorbansinya pada panjang gelombang rentang 400 $\mathrm{nm}-800 \mathrm{~nm}$ menggunakan spektrofotometri UVVis.

\section{Analisis Data}

Perhitungan rendemen didasarkan pada (Susanty dan Bachmid F., 2016):

$$
\text { Rendemen : } \frac{\text { Berat ekstrak }}{\text { Berat sampel batang tumbuhan daun ungu }} \times 100 \%
$$

Aktivitas antioksidan dari suatu bahan atau sampel, ditentukan menggunakan persamaan (Karim, et. al., 2015): $100 \%$

$\%$ Aktivitas Antioksidan : $\frac{\text { Abs.Blanko-Abs.Sampel }}{\text { Abs.Blanko }} x$

Regresi linier dari kisaran konsentrasi ekstrak dengan \% DPPH digunakan untuk menentukan konsentrasi ekstrak yang dapat menurunkan $50 \%$ DPPH (nilai IC50) (Nurisyah, et. al., 2020). Kriteria dari suatu antioksidan yaitu jika nilai IC50 kurang dari 50 maka termasuk dalam kategori sangat kuat, untuk IC50 bernilai 50-I00 masuk dalam kategori kuat, untuk IC50 bernilai I00-I50 masuk dalam kriteri sedang dan jika IC50 adalah I5I-200 masuk dalam kriteri lemah (Salim, 20I8).

\section{Hasil dan Pembahasan}

\section{Hasil ekstraksi refluks dan karakterisasi}

Proses ekstraksi merupakan suatu metode yang digunakan untuk menghasilkan kandungan komponen kimia yang larut pada suatu pelarut. Ekstraksi yang sering dilakukan pada proses pemisahan komponen bioaktif dari tanaman dalam hal mengetahui rendemen yang akan dihasilkan, yaitu ekstraksi secara panas seperti dengan cara refluks dan ekstraksi secara dingin seperti maserasi, perkolasi dan sokletasi (Kiswandono, 20II).

Dalam penelitian ini metode ekstraksi yang digunakan untuk mengekstraksi batang tanaman ungu (Graptophyllum pictum (L.) Griff) adalah secara refluks, dimana dengan metode ini waktu yang digunakan lebih singkat, terjadi kontak langsung dengan pelarut secara terus menerus, dan pelarut yang digunakan lebih sedikit sehingga efektif dan efisien.

Pada proses ekstraksi menggunakan metode refluks, sampel batang tanaman ungu yang ditimbang sebanyak \pm 25 gram dengan penambahan etanol 75 $\%$ sebagai pelarut didalamnya dan didiekstraksi dengan suhu $50^{\circ} \mathrm{C}$ selama 2 jam. Perlakuan ekstraksi dilakukan sampai 3 kali dengan menggunakan sampel batang tanaman ungu yang baru. Setelah proses evaporasi menggunakan alat rotary vacuum evaporator didapatkan ekstrak pekat kemudian dilanjutkan pada proses karakterisasi dari ekstrak. Hasil karakterisasi dari ekstrak batang tanaman ungu didapatklan berupa rendemen sebesar 8,69\%, berbentuk ekstrak pekat, berwarna coklat kehitaman, berbau khas dan rasa pahit. Hasil karakterisasi ekstrak batang tanaman ungu (Graptophyllum pictum (L.) Griff) dapat dilihat pada tabel I dan 2.

Tabel I. Nilai rendemen hasil ekstraksi refluks batang tanaman Ungu (Graptophyllum pictum (L.)

\begin{tabular}{cccc}
\multicolumn{4}{c}{ Griff } \\
No. & $\begin{array}{c}\text { Bobot Batang } \\
\text { Tanaman Ungu } \\
\end{array}$ & $\begin{array}{c}\text { Bobot } \\
\text { Ekstrak } \\
(\mathrm{g})\end{array}$ & $\begin{array}{c}\text { Nilai } \\
\text { Rendemen } \\
(\%)\end{array}$ \\
\hline I & 25 & 2,18 & 8,72 \\
2 & 25 & 2,13 & 8,52 \\
3 & 25 & 2,21 & 8,84 \\
\hline \multicolumn{2}{l}{ Rata - Rata Nilai Rendemen } & $\mathbf{8 , 6 9}$ \\
\hline
\end{tabular}

Tabel 2. Hasil karakterisasi ekstrak batang tanaman Ungu (Graptophyllum pictum (L.) Griff)

\begin{tabular}{cll}
\hline No. & Spesifikasi & Deskripsi \\
\hline I & Rendemen $(\%)$ & 8,69 \\
2 & Bentuk & Ekstrak pekat \\
3 & Warna & Coklat kehitaman \\
4 & Bau & Khas \\
5 & Rasa & Pahit \\
\hline
\end{tabular}

Pengukuran panjang gelombang serapan maksimum larutan DPPH (blanko)

Pengukuran panjang gelombang serapan maksimum larutan DPPH (blanko) dengan konsentrasi $40 \mathrm{ppm}$, setelah 30 menit diukur menggunakan Spektrofotometer Visibel, diperoleh panjang gelombang maksimumnya adalah 516,30 $\mathrm{nm}$ dengan absorbansi 0,830, sebagaimana terlihat pada gambar I. Hal ini sesuai yang dikemukakan Molyneux (2004) bahwa secara teoritis dalam mengukur suatu DPPH panjang gelombang antara $515 \mathrm{~nm}-520 \mathrm{~nm}$. DPPH adalah suatu radikal bebas yang sangat stabil pada suhu kamar serta sering dipakai dalam mengevaluasi segala aktivitas 
antioksidan dari suatu komponen kimia atau bahan alam. Elektron dari suatu radikal bebas DPPH menjadi berpasangan yang dapat dilihat dengan penghilangan warna yang sama dengan jumlah elektron yang diambil disebabkan oleh adanya aktivitas dari suatu senyawa antioksidan (Nurisyah, et.al., 2020).

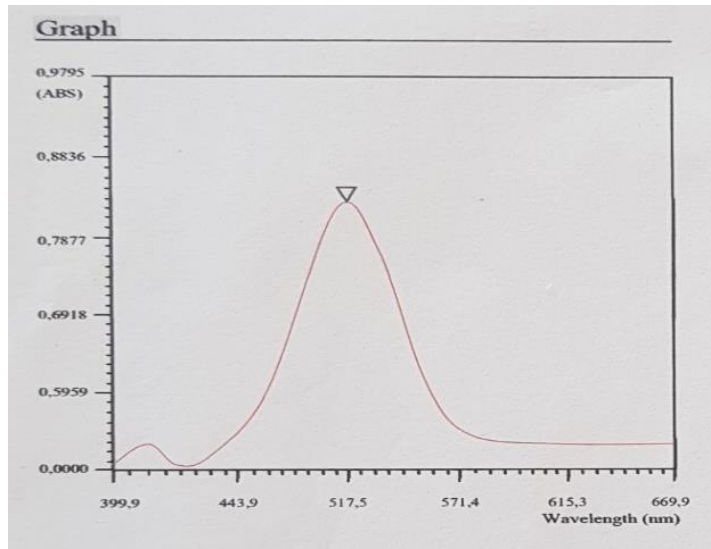

Gambar I. Spektrum Serapan DPPH 40 ppm

\section{Pengukuran aktivitas antioksidan ekstrak batang tanaman Ungu (Graptophyllum pictum (L.) Griff)}

Pengukuran aktivitas antioksidan dari larutan ekstrak batang tanaman ungu setelah direaksikan dengan larutan DPPH 40 ppm dan diinkubasi selama 30 menit lalu diukur absorbansinya pada panjang gelombang $516,30 \mathrm{~nm}$, didapatkan hasil yakni untuk 50 ppm dengan nilai absorbansi 0,662, untuk 75 ppm dengan absorbansi 0,6I5, untuk 100 ppm dengan nilai absorbansi 0,578, untuk 125 ppm dengan nilai absorbansi 0,536 dan untuk 150 ppm dengan nilai absorbansi 0,495 , sebagaimana terlihat pada gambar 2 dibawah ini.

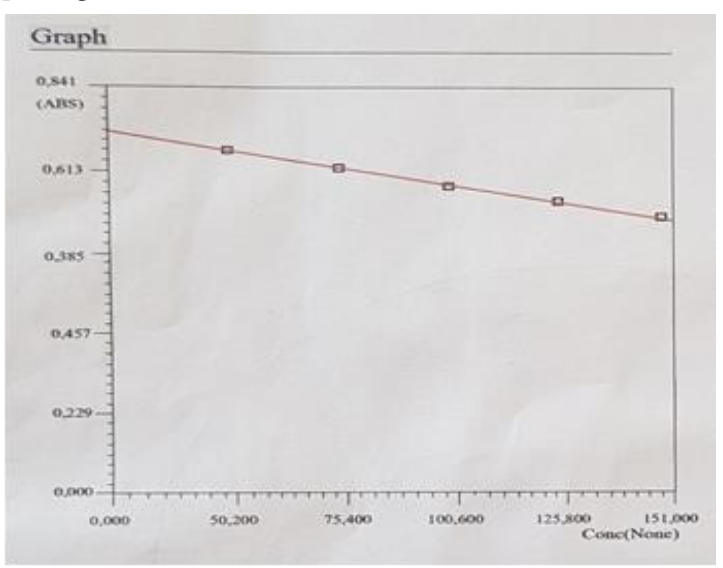

Gambar 2. Nilai absorbansi ekstrak batang tanaman ungu (Graptophyllum pictum (L.) Griff) dari $\mathrm{DPPH}$

Hasil yang didapatkan dapat diketahui bahwasanya semakin kecil nilai konsentrasi yang gunakan dalam pengukuran aktivitas antioksidan larutan ekstrak batang tanaman ungu maka semakin besar absorbansi yang didapatkan. Pernyataan ini juga sangat berkaitan dengan hukum Lambert Beer yang menyatakan bahwa suatu konsentrasi sampel berbanding lurus dengan absorbansi. Selain itu juga dipengaruhi oleh adanya penambahan pereaksi DPPH dalam sampel. Menurut Salim (2018) dan Nurisyah, et.al. (2020) menyatakan bahwa DPPH sebagai radikal bebas distabilkan oleh suatu antioksidan dengan cara melepaskan atom hidrogen sehingga akhirnya membentuk DPPH-H tereduksi dan stabil, yang ditandai adanya perubahan warna dari ungu menjadi kuning diikuti dengan penurunan serapan pada panjang gelombang yang telah ditentukan sebelumnya.

Nilai absorbansi yang diperoleh dari larutan ekstrak batang tanaman ungu dapat digunakan untuk mengetahui dan menentukan kekuatan antioksidan ekstrak batang tanaman ungu. Aktivitas antioksidan batang tanaman ungu didapatkan dari hasil perhitungan, dimana pada 50 ppm aktivitas antioksidan yang dihasilkan sebesar 20,24\%, untuk 75 ppm aktivitas antioksidan sebesar 25,90\%, I00 ppm aktivitas antioksidan sebesar 30,36\%, 125 ppm aktivitas antioksidan sebesar 35,42\%, dan yang terakhir pada 150 ppm aktivitas antioksidan sebesar 40,36\%. Hasil ini menunjukkan bahwa semakin besar konsentrasi sampel maka semakin besar pula persen aktivitas antioksidan sehingga dapat dikatakan semakin banyak pula komponen partikel zat aktif dari ekstrak batang tanaman ungu yang bekerja untuk mengoksidasi partikel DPPH sebagai radikal bebas. Aktivitas antioksidan batang tanaman ungu dapat dilihat pada gambar 3 .

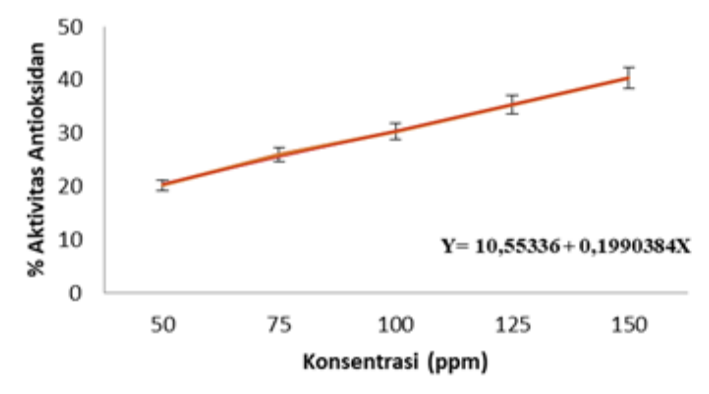

Gambar 3. Aktivitas antioksidan ekstrak batang tanaman ungu (Graptophyllum pictum (L.) Griff)

\section{Pengukuran aktivitas antioksidan vitamin $\mathrm{C}$}

Vitamin $C$ yang lebih dikenal dengan nama asam askorbat adalah suatu nutrien yang sangat penting untuk kehidupan, untuk menjaga kesehatan dan memiliki peranan penting dalam menangkal berbagai penyakit serta vitamin yang larut dalam air. Vitamin $C$ juga merupakan antioksidan terlarut air paling dikenal yang sangat efektif dalam menangkal radikal 
bebas dan aktif dalam proses Reactive Oxygen Species (ROS) (Ameliya, et. al., 2018). Vitamin C mempunyai peran sebagai senyawa antioksidan alami dengan aktivitas terlarut dalam air tinggi, tetapi karena sifatnya hidrofilik sehingga efektivitas dalam menstabilkan lemak dan minyak berkurang (Wijayati, et. al., 2016). Dalam penelitian ini, vitamin $C$ digunakan sebagai larutan pembanding untuk aktivitas antioksidan dengan beberapa variasi konsentrasi yakni 2 ppm, 4 ppm, 6 ppm, 8 ppm, dan I0 ppm. Kurva nilai absorbansi dari vitamin $C$ dapat dilihat pada gambar 4 dibawah ini.

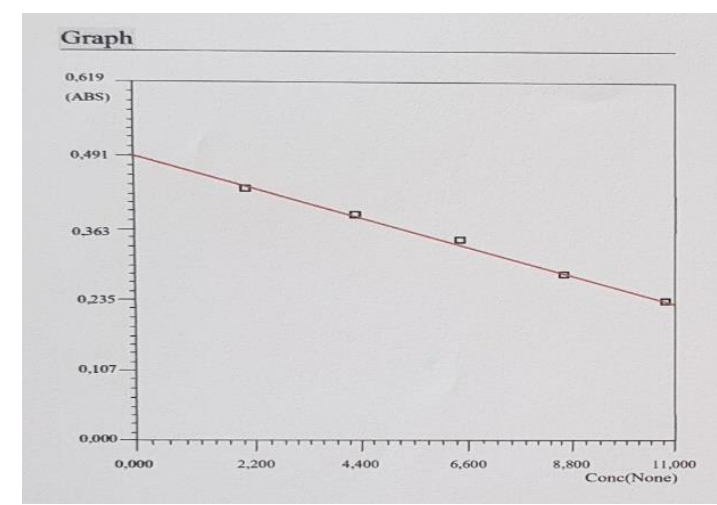

Gambar 4. Nilai Absorbansi Vitamin C

Nilai absorbansi dari pengukuran antioksidan $\mathrm{C}$ sesudah direaksikan dengan larutan DPPH 40 ppm serta diinkubasi selama 30 menit lalu diukur absorbansinya pada panjang gelombang $516,30 \mathrm{~nm}$, didapatkan hasil yakni untuk 2 ppm dengan nilai absorbansi 0,434 , untuk 4 ppm nilai absorbansi 0,384 , untuk 6 ppm dengan nilai absorbansi 0,342 , untuk 8 ppm dengan nilai absorbansi 0,284 dan I0 ppm dengan nilai absorbansi 0,235. Hasil nilai absorbansi yang didapatkan sangat jelas memperlihatkan hubungan yang linier, dimana semakin kecil nilai konsentrasi semakin besar absorbansi yang didapatkan. Ini menandakan bahwa dalam meredam sifat radikal bebas dari DPPH hanya sebagian kecil komponen partikel antioksidan dari vitamin $\mathrm{C}$ yang digunakan.

Nilai absorbansi yang diperoleh digunakan untuk menghitung aktivitas antioksidan dari vitamin C sebagai larutan pembanding. Aktivitas antioksidan vitamin $\mathrm{C}$ didapatkan dari hasil perhitungan, dimana pada 2 ppm aktivitas antioksidan sebesar 47,71\%, 4 ppm aktivitas antioksidan sebesar 53,73\%, 6 ppm aktivitas antioksidan sebesar 58,75\%, 8 ppm aktivitas antioksidan sebesar $65,78 \%$, dan pada 10 ppm aktivitas antioksidan sebesar 71,68\%. Hasil ini memperlihatkan bahwa semakin kecil konsentrasi vitamin $\mathrm{C}$ maka semakin kecil pula persen aktivitas antioksidan yang didapatkan. Tetapi ketika nilai suatu aktivitas antioksidan yang semakin besar dengan konsentrasi yang besar pula maka komponen partikel vitamin $\mathrm{C}$ yang dibutuhkan dalam mengoksidasi DPPH sebagai radikal bebas semakin banyak. Aktivitas antioksidan vitamin $\mathrm{C}$ dapat dilihat pada gambar 5 .

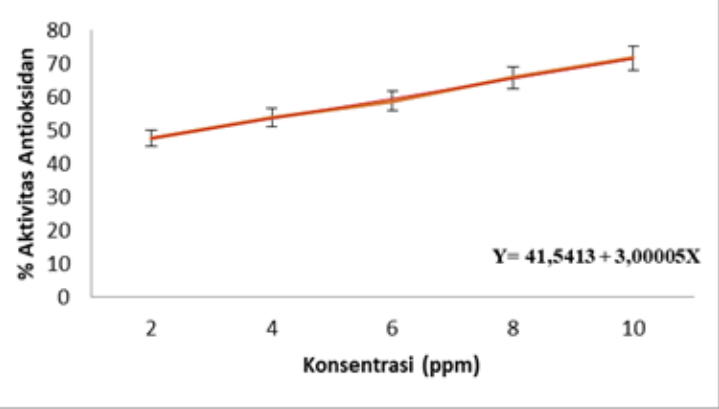

Gambar 5. Aktivitas Antioksidan Vitamin C

Perhitungan IC50 ekstrak batang tanaman ungu (Graptophyllum pictum (L.) Griff) dan Vitamin C

IC50 adalah suatu jenis parameter yang dapat digunakan dalam mengetahi dan menentukan kekuatan suatu bahan atau senyawa dalam menghambat aktivitas oksidan dari DPPH sebesar $50 \%$. Ini menunjukkan bahwa semakin tinggi aktivitas antioksidan suatau bahan maka semakin kecil nilai IC50 yang didapatkan (Molyneux, 2004). Secara karakteristik suatu senyawa atau bahan dikatakan sebagai antioksidan, jika nilai IC50 kurang dari 50 bersifat sangat kuat, IC50 bernilai 50-100 bersifat antioksidan kuat, IC50 bernilai I00-I50 bersifat antioksidan sedang, dan IC50 bernilai I5I200 bersifat antioksidan lemah (Karim, et. al., 2015 ; Salim, 2018).

Ketika pengukuran suatu persen inhibisi diperoleh maka dibuat persamaan regresi linear menggunakan aplikasi pengolah data dalam Microsoft excel. Koefisen y pada data linear bernilai 50 merupakan koefisien IC50, sedangkan koefisien x pada data ini merupakan konsentrasi fraksi, dimana $x$ yang didapatkan adalah besar konsentrasi yang digunakan untuk meredam aktivitas radikal DPPH (Sinala dan Dewi, 2019). Hasil dari masing-masing kurva regresi adalah untuk ekstrak batang tanaman ungu adalah $\quad y=10,55336+0,1990384 x$ dan untuk vitamin $\mathrm{C}$ persamaan kurva regresi adalah $\mathrm{y}=$ 4I,54I3 + 3,00005x.

Berdasarkan hasil perhitungan nilai IC50 untuk ekstrak batang tanaman ungu (Graptophyllum pictum (L.) Griff) sebesar 198,186 ppm dan untuk vitamin $C$ sebesar 2,8I9 ppm. Secara spesifik yang didasarkan dari hasil nilai IC50 maka ekstrak batang tanaman ungu (Graptophyllum pictum (L.) Griff) termasuk dalam kategori antioksidan lemah 
(mendekati tidak aktif) sedangkan vitamin C termasuk dalam kategori antioksidan sangat kuat.

Adanya kandungan antioksidan dalam ekstrak batang tanaman ungu (IC50, I98,I86 ppm) kemungkinan disebabkan oleh beberapa faktor, menurut Wiraatmaja (20I7) bahwa tumbuhan mengalami suatu proses metabolisme yang terdiri atas reaksi penyusunan (anabolisme) yaitu pembentukan senyawa yang lebih besar dari molekul yang lebih kecil, misalnya proses fotosintesis dan reaksi pemecahan (katabolisme) yang memecah molekul besar menjadi molekul yang lebih kecil dan menghasilkan energi, misalnya respirasi. Sel-sel dalam tubuh tumbuhan mampu mengatur jalur metabolisme yang dapat dikendalikan sehingga dapat terjadi dan dapat mengatur kecepatan reaksi tersebut dengan menghasilkan jumlah katalis yang tepat saat dibutuhkan. Katalis ini disebut enzim yang mampu mempercepat laju reaksi mulai dari I08 hingga I020.

Selain itu, adanya faktor proses difusi, transpor aktif dan proses osmosis yang memindahkan suatu zat atau partikel senyawa dalam jaringan tanaman serta adanya zat pengatur tumbuh yaitu molekul organik yang dihasilkan oleh satu bagian tanaman dan diangkut ke bagian lain yang mempengaruhinya. Kehadirannya di dalam sel pada tingkat yang sangat rendah memicu proses transkripsi RNA. Hormon tumbuhan sendiri dirangsang untuk terbentuk melalui sinyal berupa aktivitas senyawa reseptor sebagai respon terhadap perubahan lingkungan yang terjadi di luar sel (Khairuna, 2019). Semakin banyak metabolit sekunder yang terkandung, semakin kuat aktivitas antioksidannya. Hal ini menunjukkan bahwa tingkat pertumbuhan (umur tanaman) mempengaruhi metabolit sekunder yang memiliki senyawa aktivitas antioksidan (Bahriul, et. al., 20I4).

Tetapi pada dasarnya antioksidan yang terdapat pada batang tanaman ungu relatif sangat kecil dan bisa dikatakan mendekati tidak aktif dibandingkan dengan antioksidan yang terdapat pada bagian daunnya, rata - rata dari suatu penelitian mengemukakan bahwa daun tanaman ungu memiliki antioksidan aktif ( $\mathrm{IC}_{50}$ ) berkisar antara 50-I00 dan IOO-I50.

\section{Simpulan dan Saran}

Berdasarkan hasil penelitian dapat disimpulkan bahwa ekstrak batang tanaman Ungu (Graptophyllum pictum (L.) Griff) memiliki aktivitas antioksidan lemah dilihat dari nilai IC50 yaitu berada pada konsentrasi 198,186 ppm (antioksidan lemah).

Berdasarkan hasil penelitian yang telah dilakukan pada ekstrak batang tanaman Ungu (Graptophyllum pictum (L.) Griff) dan berbagai telaah literatur maka disarankan lebih lanjut untuk dilakukan penelitian pada aktivitas lainya agar didapatkan sumber informasi yang lebih banyak pada ekstrak batang tanaman ungu sehingga kedepannya bisa dijadikan acuan dalam memformulasi suatu sediaan obat tradisonal maupun herbal.

\section{Daftar Pustaka}

Ameliya, R., Nazaruddin, Handito D. (2018). Pengaruh Lama Pemanasan Terhadap Vitamin C, Aktivitas Antioksidan dan Sifat Sensoris Sirup Kersen (Muntingia calabura L.). Pro Food Jurnal Ilmu dan Teknologi Pangan, 4(I), 289-297.

Andiyani R., Yuniarni U., Mulyanti D., (2015). Uji Efektivitas Daun Wungu (Graptophyllum pictum (L.) Griff) Sebagai Penyembuh Luka. Prosiding Farmasi SPeSIA Unisba.

Bahriul, P., Rahman, N., Diah, A.W.M. (20I4). Uji Aktivitas Antioksidan Ekstrak Daun Salam (Syzygium polyanthum) Dengan Menggunanakan I,I-Difenil-2Pikrilhidrazil. Jurnal Akademika Kimia, 3(3), I43-I49.

Bangun, A. (2012). Ensiklopedia Tanaman Obat Indonesia. Bandung: IPH.

Dewantari R., Lintang M. L., Nurmiyati, (2018). Jenis Tumbuhan yang Digunakan sebagai Obat Tradisional Di Daerah EksKaresidenan Surakarta. Jurnal Bioedukasi, I I(2), I I 8- I23.

Fauzi, D. (2016). Aktivitas Antibakteri Ekstrak Daun Ungu (Graptophyllum pictum L.) Terhadap Staphylococcus aureus dan Pseudomonas aeruginosa. Journal of Chemical Information and Modeling, i-80. http://ejournal.uajy.ac.id/id/eprint/I 236.

Gill, M.I., Tomas-Barberan, F.A., Hess-Pierce, B. and Kader, A.A. (2002), Antioxidant Capacities, Phenolic Compounds, Carotenoids, and Vitamin C Contents of Nectarine, Peach, and Plum Cultivars from California, J. Agric. Food Chem. 50 (I7), 4976-82.

Haeria. (2013). Penetapan Kadar Flavonoid Total dan Uji Daya Antioksidan Ekstrak Etanol Daun Ungu (Graptophyllum pictum L .) Griff). JF FIK UINAM, I(I), I-9.

Herman, (2013). Aktivitas Antioksidan Beberapa Tumbuhan Obat Kalimantan Timur. J. Trop. Pharm, 2(2), 100 - 104. 
Karim, K., Jura, M.R., Sabang, S.M. (2015). Uji Aktivitas Antioksidan Ekstrak Daun Patikan Kebo (Euphorbia hirta L.). Jurnal Akademika Kimia, 4(2), 56-63.

Khairuna. (2019). Diktat Fisiologi Tumbuhan. Fakultas Ilmu Tarbiyah Dan Keguruan, Universitas Islam Negeri Sumatera Utara, Medan.

Kiswandono, A.A. (201I). Skrining Senyawa Kimia dan Pengaruh Metode Maserasi dan Refluks pada Biji Kelor (Moringa oleifera, Lamk) terhadap Rendemen Ekstrak yang Dihasilkan. Jurnal Sains Natural Universitas Nusa Bangsa, I(2), I26 - I34.

Kementerian Kesehatan Republik Indonesia, (2012). Vandemekum Tanaman Obat Untuk Saintifikasi Jamu. Jilid I (edisi revisi). Badan Litbang Kesehatan, Departemen Kesehatan RI, Jakarta, 78-79.

Lobo V., Patil A., Phatak A., Chandra N. (2010). Free Radicals, Antioxidants and Functional Foods: Impact on Human Health. Pharmacogn, Rev. 4, II8-I26.

Manoi F. (2010). Analisa Fitokimia dan Kandungan Bahan Aktif dari Lima Aksesi Tanaman Handeuleum (Graptophyllum pictum (L.) Griff). Jurnal Penelitian Pertanian Terapan, II(I), I5-24.

Molyneux, P. (2004). The Use Of The Stable Frre Radicals Diphenylpicrylhydrazyl (DPPH) For Estimating Antioxidant Activity. Songklanakarin Journal of Science Technology, 26(2), 2II-219.

Nurisyah, Asyikin, A., Cartika, H. (2020). Aktivitas Antioksidan Krim Ekstrak Etil Asetat Kulit Jeruk Nipis (Citrus aurantifolia) Yang Ditetapkan Dengan Metode DPPH. Media Farmasi, XVI(2), 215-22I. DOI: https://doi.org/I0.32382/mf.vI6i2.I8I 8

Nurisyah, Barung, E.N., and Salasa, A.M. (2020). Antixodant Activity of Black Soybean Extract (Glycine Soja) by the DPPH (I,IDiphenyl-2-Pcrylhydrazyl) Method. Easy Chair Preprint No. 4I23. https://easychair.org/publications/prepri $\mathrm{nt} / \mathrm{Czt} 7$

Nurwijayanto A., Na'iem M., Syahbudin A., Wahyuono S. (2020). Eksplorasi Potensi Antioksidan Tumbuhan Obat dari Taman Nasional Gunung Merapi Yogyakarta. ResearchGate : Jurnal Tumbuhan Obat Indonesia, I3(I), 25-3I.
Parwata, M.O.A. (2016). Antioksidan. Bahan Ajar, Program Pascasarjana, Universitas Udayana, Denpasar.

Purwaningsih D. (2019). Induksi Kalus Daun Ungu (Graptophyllum pictum (L.) Griff) Pada Media MS (Murashige \& Skoog) Kombinasi Fitohormon 2,4-D (2,4 Diklorofenoksiaasetat) dan BAP (6Benzilaminopurine). Skripsi. Fakultas Sains dan Teknologi, Universitas Islam Negeri Sunan Kalijaga, Yogyakarta. https://digilib.uinsuka.ac.id/id/eprint/34 $47 \mathrm{I} /$

Qulbi, L. (2017). Etnobotani tumbuhan berpotensi obat karies gigi pada masyarakat Kecamatan Besuk Kabupaten Probolinggo dan uji aktivitas antibakteri Streptococcus mutans. Undergraduate thesis, Universitas Islam Negeri Maulana Malik Ibrahim.

Rustini N.L, Ariati, N.K. (2017). Aktivitas Antioksidan Dari Ekstrak Etanol Daun Ungu. Cakra Kimia (Indonesian E-Journal of Applied Chemistry), 5(2), I45-I5I.

Salim, R. (2018). Uji Aktivitas Antioksidan Infusa Daun Ungu Dengan Metoda DPPH (I,Idiphenil- 2-picrylhidrazil). Jurnal Katalisator. 3(2), I53-I6I.

Salim, R. dan Suryani. (2020). Aktivitas Antioksidan si Ungu Mentawai. Jurnal Katalisator, 5(I), I7-3I.

Sari A.N. (2016). Berbagai Tanaman Rempah Sebagai Sumber Antioksidan Alami Elkawnie: Journal of Islamic Science and Technology, 2(2), $203-212$.

Sinala, S. dan Dewi S.T.R. (2019). Penentuan Aktivitas Antioksidan Secara In Vitro Dari Ekstrak Etanol Propolis Dengan Metode DPPH (I,I-Difenil-2-Pikrilhidrazil). Media Farmasi, XV(I), 9I-96. DOI: https://doi.org/I0.32382/mf.vI5iI.820

Sumarny, R., Yuliandini., dan Rohani, M. (2013). Efek Antiinflamasi dan Antidiare Ekstrak Etanol Herba Meniran (Phylanthus niruri L.) dan Daun Ungu (Graptophyllum pictum L.). Skripsi. Fakultas Farmasi, Universitas Pancasila, Jakarta.

Susanty dan Bachmid F. (2016). Perbandingan Metode Ekstraksi Maserasi dan Refluks terhadap Kadar Fenolik dari Ekstrak Tongkol Jagung (Zea mays L.). Jurnal KONVERSI, 5(2), 87 -93.

Sya'haya, S. dan Iyos, R.N. (2016). Pengaruh Pemberian Ekstrak Daun Ungu (Graptophylum pictum Griff) terhadap 
Penyembuhan Hemoroid. MAJORITY, 5(5), I55-I60.

Theresia R.KA. (2012). Potensi Ekstrak Etanol Daun Wungu (Graptophyllum pictum (L.) Griff) Pada Tikus Sprague-Dawley Diabetes Yang Diinduksi Aloksan. Skripsi. Fakultas Matematika dan Ilmu Pengetahuan Alam, Institut Pertanian Bogor, Bogor. https://repository.ipb.ac.id/handle/I234 $56789 / 64695$

Wahyuningtyas, E. (2008). Pengaruh Ekstrak Graptophyllum pictum Terhadap Pertumbuhan Candida albicans Pada Plat Gigi Tiruan Resin Akrilik. Indonesian Journal of Dentistry, I5(3), I87-I9I.

Wijayati, N., Rohmah, S.A., Supartono. (2016). Sintesis Ester-C Sebagai Senyawa Antioksidan Menggunakan Biokatalis Enzim Lipase/Zeolit Alam. Journal Kimia Riset, I(I), 7-I3.

Wiraatmaja, W. (2017). Bahan Ajar Metabolisme Pada Tumbuhan. Fakultas Pertanian, Universitas Udayana, Denpasar. 